\title{
Tumor Necrosis Factor Receptor Superfamily Member 10D
}

National Cancer Institute

\section{Source}

National Cancer Institute. Tumor Necrosis Factor Receptor Superfamily Member 10D. NCI Thesaurus. Code C159373.

Tumor necrosis factor receptor superfamily member 10D (386 aa, $42 \mathrm{kDa}$ ) is encoded by the human TNFRSF10D gene. This protein plays a role in cell survival. 